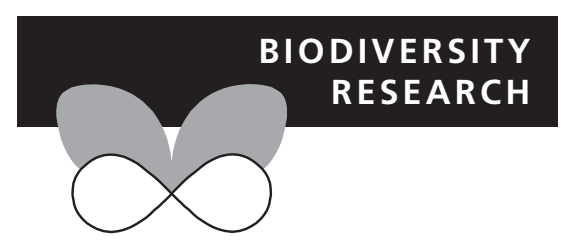

\title{
Global conservation strategies for two clades of snakes: combining taxon-specific goals with general prioritization schemes
}

Levi Carina Terribile ${ }^{1 \star}$, Guilherme de Oliveira² , Fábio Albuquerque ${ }^{3}$, Miguel Ángel Rodríguez ${ }^{3}$ and José Alexandre Felizola Diniz-Filho ${ }^{2}$

${ }^{1}$ Universidade Federal de Goiás, Campus Jataí

- Unidade Jatobá. Rod. BR-364, KM 192, CP

03, CEP: 75800-970, Jataí-GO, Brazil,

${ }^{2}$ Departamento de Ecologia, ICB,

Universidade Federal de Goiás, CP 131,

74.001-970, Goiânia, GO, Brazil,

${ }^{3}$ Department of Ecology, University of Alcalá, 28871 Alcalá de Henares, Spain

${ }^{*}$ Correspondence: Levi Carina Terribile, Universidade Federal de Goiás, Campus Jataí Unidade Jatobá. Rod. BR-364, KM 192, CP 03, CEP: 75800-970, Jataí-GO, Brazil.

E-mail: levicarina@gmail.com

\begin{abstract}
Aim We present the first attempt of mapping global conservation priorities for two snake clades, Viperidae and Elapidae. We compared the global conservation priorities of each clade with the nine global conservation schemes defined by Brooks et al. to evaluate how effective these schemes are in ensuring the preservation of viperid and elapid biodiversity.
\end{abstract}

Location Global.

Methods Based on range maps of 228 species of Viperidae and 224 species of Elapidae, we used systematic conservation planning methods of complementarity and irreplaceability to generate a set of conservation networks under two cost scenarios: (1) minimizing conservation-human development conflicts and (2) maximizing environmental suitability for high snake richness. Analysis of variance was used to investigate whether the mean irreplaceability of cells matching the areas covered by each of the nine global prioritization schemes in Brooks et al. was higher than the mean irreplaceability of cells located outside these areas.

Results Overall, few areas showed irreplaceability higher than 0.5 based on a goal of representing $25 \%$ of the species' ranges. The conservation networks generated in expectation of low conflicts between human development and conservation were quite different from the networks of high environmental suitability. Areas with higher irreplaceability coincided with the regions covered by global schemes of Endemic Bird Areas (for Viperidae and Elapidae) and High-Biodiversity Wilderness (for Elapidae).

Main conclusions Our findings indicated the existence of viable conservation opportunities for these two snake groups. This study can be viewed as a way to overcome, at least in part, the recent criticism concerning the independent development of several global conservation priorities by evaluating which groups of organisms are better represented in each of them. More than simply determining priorities for snakes' conservation, our analyses showed that the development of parallel priority-setting initiatives can be reconciled with those strategies for which financial resources are already being designed.

\section{Keywords}

Biodiversity, complementarity, global conservation priorities, reserve network, snakes.

\section{INTRODUCTION}

The accelerated expansion of human activities in detriment of natural environments has caused irreversible biodiversity losses world-wide (Ehrlich, 1994; Pimm et al., 1995). In response to an imminent crisis in biodiversity, several global schemes of prioritization have been developed in recent years, particularly by non-governmental organizations, aimed at identifying regions of high conservation value (e.g., Bryant et al., 1997; Stattersfield et al., 1998; Myers et al., 2000; see Brooks et al., 
2006 for a recent review). However, such global schemes differ in respect to the nature of the conservation target, where or how conservation should be done, as well as in the principles underlying each approach (Redford et al., 2003). In this sense, they can be conceptually distinguished in two main groups: those that prioritize regions of high threat and high irreplaceability and those that prioritize regions of low threat but high irreplaceability (i.e., the 'purely reactive' and the 'purely proactive' approaches, respectively; sensu Brooks et al., 2006).

Reactive approaches focus on pressing regions where human disturbance to natural habitats has been harsh and for which conservation actions are most urgent to prevent more biodiversity loss - e.g., the Biodiversity Hotspots and the Crisis Ecoregions, originally defined by Myers et al. (2000) and Hoekstra et al. (2005), respectively. Conversely, the proactive approaches focus on regions of high conservation value where current exploitation, although low, may result in a severe species loss in the future - e.g., the High-Biodiversity Wilderness Areas and the Frontier Forests of Mittermeier et al. (2003) and Bryant et al. (1997), respectively. Other global schemes may still be ranked between these two frameworks, which actually represent the extremes of a continuous axis, in the extension to which they prioritize irreplaceability or vulnerability (see Brooks et al., 2006).

Most of the global schemes have emphasized the conservation of plants (WWF \& IUCN, 1994-1997; Bryant et al., 1997), and birds (Stattersfield et al., 1998), and other global priorities have been mapped for amphibians (IUCN et al., 2006), and mammals (Ceballos et al., 2005; Carwardine et al., 2008). These organisms have benefited from the accumulation of biodiversity data applied for conservation purposes at large scale and, consequently, have attracted substantial research efforts and conservation funding (Fonseca et al., 2000). Unfortunately, the availability of datasets and conservation plans at broad scale for other groups, such as squamate reptiles (lizards, snakes and amphisbaenians), is still scarce.

Population declines and geographical range contractions have been documented for most of the snake species around the world (e.g., Dodd, 1987, 1993; Jaggi \& Baur, 1999; Nilson et al., 1999; Gibbons et al., 2000; Terribile et al., 2007). Forest degradation and habitat loss together with associated characteristics, such as habitat specialization, small home-range size, low dispersal rate, low reproductive frequency and the restricted distribution of prey species included in their diet (Zamudio \& Greene, 1997; Gibbons et al., 2000; Reed \& Shine, 2002; Webb et al., 2002; Campbell \& Lamar, 2004; Santos et al., 2006; Terribile et al., 2007), make most snake species particularly susceptible to habitat changes and, ultimately, highly vulnerable to extinction (Santos et al., 2006). Although these organisms have been less studied than other groups, considerable efforts have been expended to identify snake conservation priorities (e.g., Akani et al., 1999; Cogger et al., 2000; Filippi \& Luiselli, 2000; Brooks et al., 2001; Moore et al., 2003; Zhou \& Jiang, 2005; Couto et al., 2007; Cagle, 2008). However, the majority of these studies have been based on small sample sizes of snake diversity (but see Cogger et al.,
2000 and Reed \& Shine, 2002), and the unavailability of data has prevented the development of global-scale conservation strategies.

In this study, we used a global dataset of Viperidae and Elapidae species distributions to generate the first global model of snake conservation priorities based on systematic conservation planning methods (i.e., complementarity and irreplaceability) (Margules \& Pressey, 2000). Although these two families of venomous snakes represent only about $25 \%$ of snake richness (Kelly et al., 2003), they are relatively well known in their distributional patterns given their medical importance. More importantly, our recent analyses (see Terribile et al., 2009) show that richness and distribution of these two snake groups are driven by distinct ecological and evolutionary processes, providing a good opportunity to understand both the mechanisms driving macroecological patterns and their consequences for establishing broad-scale conservation strategies.

Complementarity approaches may give us an efficient answer to the question of what locations should be included in a representative conservation network (Brooks et al., 2001), but even so conservationists have insisted that effective conservation planning must deal not only with the representation of species, but also with potential conflicts between biodiversity conservation and human development (Margules \& Pressey, 2000; Balmford et al., 2001, 2003; Chown et al., 2003; Diniz-Filho et al., 2006; Bode et al., 2008; Loyola et al., 2008). Thus, defining strategies for broad-scale conservation planning based on species richness should be carried out by taking into account the environmental factors associated with biodiversity patterns at these scales (Bini et al., 2006). Consequently, the effectiveness of systematic conservation planning results in part from its efficiency in preserving environmentally important regions for maintenance of species richness without overlapping with economically important areas. Based on these two premises, we also generated conservation networks that represent the total species richness of each group with a minimum of human influence and a maximum of environmental suitability.

Additionally, we compared the global pattern of irreplaceability and conservation networks obtained for each snake family with the nine global conservation priorities recently defined by Brooks et al. (2006), to evaluate how effective these schemes are in ensuring the preservation of viperid and elapid biodiversity. Thus, the combination of the global priority maps (generated by these authors under the criteria of reactive and proactive approaches) and the global picture of irreplaceability established for viperid and elapid snakes will provide us with a general understanding of the current level of threat facing the most important areas for these two groups. Moreover, we designed a way to evaluate how these global schemes achieve conservation goals for a particular group of organisms. In a long run, this can be a helpful way to establish relative efficiency of each of these schemes and understand in which situations they can be more useful for conservation purposes. 


\section{METHODS}

\section{Data}

We generated a global checklist of Viperidae and Elapidae species based on the updated Reptile Database supported by the Systematics Working Group of the German Herpetological Society (Uetz, 2007). Given that our conservation planning analyses focused on continental species, we excluded insular and sea snake species, aside from those found in the wellprospected island of Great Britain. Data scarcity for the Arabian Peninsula also precluded including this region in the analyses. Our final dataset comprised 228 viperids and 224 elapids (see Terribile et al., 2009, for a full list of genera and number of species), for which maps of geographical distribution were compiled from several sources of species distribution world-wide.

For the New World, species range maps were primarily obtained from Campbell \& Lamar (2004), supplemented with the new species recently recognized by Renjifo \& Lundberg (2003), Alvarado-Díaz \& Campbell (2004) and Lavin-Murcio \& Dixon (2004). For the Old World, we used those obtained by Branch (1988, 1998), Latifi (1991), Arnold (2002), Arnold \& Ovenden (2002), Broadley \& Doria (2003), Spawls et al. (2004), Ananjeva et al. (2006), Vogel (2006), Dobiey \& Vogel (2007), supplemented by Cherlin (1981), Orlov \& Tuniyev (1990), Tuniyev \& Ostrovskikh (2001), Khan (2002), Mallow et al. (2003) and Geniez \& Tynié (2005). For Australian elapids, we used those obtained by Wilson \& Swan (2003).

All distribution maps were digitized and rasterized in ArcGIS 9.2 in grid systems of $110 \times 110 \mathrm{~km}$ (i.e., equalling $1^{\circ}$ latitude by $1^{\circ}$ longitude at the equator) using region-specific equal area projections. For comparative purposes, the nine global scenarios analysed by Brooks et al. (2006; see Appendix 1) were also processed in the same grid of $110 \times 110 \mathrm{~km}$, denoting the presence (1) or absence (0) in each grid cell. Cells containing $<50 \%$ of the land mass were not included in the analyses to avoid potential area effects in the results.

\section{Conservation planning analyses and comparisons with global priorities}

To identify specific patches or cells representing optimum (or near-optimum) conservation networks for viperid and elapid snakes across the world, we used methods based on biodiversity complementarity (Faith et al., 2003). These methods are used to estimate the gain in species representation when adding an area (i.e., a cell) to a set of pre-selected areas (Williams, 1998; Faith et al., 2003), so that certain areas would be selected because they have the most species between them, but not necessarily the most species richness individually. The resulting pattern is a combination of areas (cells) that have the highest representation of species (Williams, 1998).

Based on the occurrence of the viperid and elapid species in the grid cells across the globe (i.e., a total of 9563 cells for viperid and 9627 cells for elapid species), we used the simulated annealing algorithm implemented on Site Selection Mode (SSM) of sites v. 1.o software program (Andelman et al., 1999) to select the minimum number of cells necessary to represent at least $25 \%$ of each species' geographical range. This strict conservation goal was used to ensure that all species would be conserved in most solutions within a minimal area needed to support viable populations. These analyses were performed for both snake families with $1 \times 10^{7}$ interactions and 150 repeated runs.

The frequency of each cell in the various optimized networks indicates its relative importance for the complementary solutions, and was used in this study to estimate and map the irreplaceability of cells (Ferrier et al., 2000; Meir et al., 2004). The irreplaceability values vary between 0 and 1 , so that cells with values of 1 (i.e., completely irreplaceable cells) are essential for achieving one or more conservation goals, whereas cells with decreasing values have increasing numbers of potential replacements to preserve the targets and achieve the established goals (Ferrier et al., 2000; Carwardine et al., 2007).

Several studies have shown that water and energy availability are among the most important drivers of species richness at large scales (e.g., Currie, 1991; Hawkins et al., 2003a; Currie et al., 2004; O'Brien, 2006), and this was also recently confirmed for viperid and elapid richness (see Terribile et al., 2009). To take into account the influence of environmental variables on determining macroscale species richness variation, we defined a cost value to each grid cell as the inverse of actual evapotranspiration (AET, available in http://www.grid.unep. ch/data/data.php), which represents the joint availability of energy and water in the environment (see Currie, 1991 and Hawkins et al., 2003a). The purpose was to generate a global network that represents all species in a set of areas having suitable environmental conditions to support high richness.

Possible conflicts between biodiversity conservation and human development were taken into account by adding a cost variable of 'human footprint' (available in http://www. ciesin.columbia.edu/download_data.html) representing human influence to each grid cell. Human footprint (hereafter HF) is a quantitative index of human activity in every biome on the land surface, built by the combination of geographical data on human population density, land transformation, accessibility and electrical power infrastructure (see details in Sanderson et al., 2002).

Thus, we generated a set of four reserve networks (i.e., two for each snake clade) that represent all species at least once under two cost scenarios: (1) maximizing AET by finding a combination of cells whose sum of the inverse of AET is the lowest in the set of selected cells; and (2) minimizing human influence by finding a combination of cells with the lower human footprint value in each grid cell. In both cases, the same SSM protocol described above was used by performing optimization routines of 50 runs and $2 \times 10^{7}$ interactions, analysing the solution with the lowest cost. The two networks for each snake group were then overlaid and the Sorensen similarity coefficient (Krebs, 1998) was used to compare how concordant the complementary solutions with different costs 
are. Sorensen coefficients near to 1 (high similarity) would indicate that cells selected in the optimum reserve network of low human influence were also selected in the optimum reserve network of high AET. For comparative purposes, we also calculated the amount of area (in number of $110 \times 110 \mathrm{~km}$ cells) of the reserve networks in each biogeographical region as defined by Cox (2001): African, Australian, Eurasian, North American, Oriental and South American.

Finally, the irreplaceability of cells was used to evaluate which of the global schemes summarized by Brooks et al. (2006) (see Table 2 and Brooks's et al., 2006 Supporting Online Material in http://www.sciencemag.org/cgi/content/full/313/ $5783 / 58 /$ DC1 for details) support the most irreplaceable areas for Viperidae and Elapidae. By setting irreplaceability as our dependent variable, we used a single classification analysis of variance (ANOVA; Sokal \& Rohlf, 1995) to investigate whether the mean irreplaceability of cells matching the areas covered by each of the nine global prioritization schemes [our independent variable of presence (1) and absence (0) of priority region in each scheme] is higher than the mean irreplaceability of cells located outside these areas. Thus, we were able to identify which global scheme best fits the areas of high conservation value for viperid and elapid biodiversity identified in this study. Before the ANOVA, grid cells containing zero species were excluded from the analyses.

\section{RESULTS}

Overall, few cells showed irreplaceability higher than 0.5 , which indicates that the combinations of cells were highly variable in each one of the 150 optimized solutions. Cells with high irreplaceability for both groups are evident across Central and North America, and Central Africa (Fig. 1a, b), although irreplaceable areas of viperids were more scattered across continents than those of elapids (except in Australia where viperids are absent). This is expected given the wider coverage of Viperidae distributions world-wide.

For Viperidae, the global networks that collectively met the established conservation goals (i.e., to represent at least $25 \%$ of species ranges) with a minimum cost were achieved with a total of 1527 cells for AET (i.e., cells with highest AET values) and 1638 cells for human influence (i.e., cells with lowest HF values) (15.9 and $17.1 \%$, respectively, of the total of cells analysed for this taxon; Table 1, Fig. 2a). For Elapidae, these goals were represented in two networks, one with 986 cells for AET and the other with 1089 cells for HF (10.2 and 11.3\%, respectively, of the total cells analysed for this taxon; Fig. 2b). Oriental and Australian were the two biogeographical regions with the largest number of cells included in the reserve networks for Viperidae and Elapidae, respectively (Table 1; see also Fig. 2).

Sorensen coefficient was low for both taxa $(0.30$ for Viperidae and 0.28 for Elapidae), indicating that conservation management plans based on the strategies trying to minimize conservation-human development conflicts cannot ensure the preservation of those areas of high snake richness (Fig. 2, see also Table 1). Indeed, the overlapping of the two types of networks indicated that only 458 cells $(4.7 \%)$ for viperids and 295 cells $(3.0 \%)$ for elapids were represented in both solutions.

Analysis of variance showed that the regions covered by the nine global conservation priorities summarized by Brooks et al. (2006), except Last of the Wild areas (Sanderson et al., 2002), represent a gain in irreplaceability in comparison with regions not covered by them (Table 2). For viperids, areas with higher irreplaceability coincided with the regions covered by Endemic Bird Areas and High-Biodiversity Wilderness Areas. For elapids, considerable gain in irreplaceability was also found in Endemic Bird Areas, but the areas falling within the Last of the Wild regions represent a loss of irreplaceability in comparison with the cells outside of this priority.

For both Viperidae and Elapidae, the same global models for which a gain in irreplaceability was previously identified were also the most efficient ones in representing high proportion of complementary areas selected by solutions maximizing AET (i.e., 25\% of cells in the AET cost solutions were represented in Endemic Bird Areas and High-Biodiversity Wilderness Areas, see Table 2). Conversely, for the solution minimizing human influence, a highest percentage of cells were represented in Last of the Wild areas. This is expected given that the Last of the Wild zones represent the least influenced areas of each biome across the world (Sanderson et al., 2002). It is also important to note that, although the Last of the Wild areas comprise almost $30 \%$ of the cells from the HF lower cost solution for elapids, they also represented a loss of irreplaceability for this group given that the areas encompassed by this scheme have lower values of irreplaceability.

\section{DISCUSSION}

In general, cells required to meet the goal of preserving at least $25 \%$ of each snake species' geographical range presented low irreplaceability values, although relatively highly irreplaceable areas were registered virtually in all continents. Low mean irreplaceability of the cells suggests that there may be more opportunities for conservation available in any given region, which can enhance the practical solutions to preserve viperid and elapid species in most areas of the world (assuming that this goal is enough for long-term persistence of the species). Moreover, it is important to consider that we did not include species from islands, many of which are endemic (e.g., Melanesian elapids). An increase of irreplaceability towards the areas encompassing these island endemics would likely be observed if they were included in the analyses (see Ferrier et al., 2000), but the absence of island species do not prevent us from a comprehensive assessment of the conservation status of these snakes across the continental mainland areas of the globe and the comparison with Brooks et al. (2006) global prioritization sets.

The accelerated human development and the constant demand for food production require the reconciliation of conflicts between areas of high values for biodiversity 
(a)
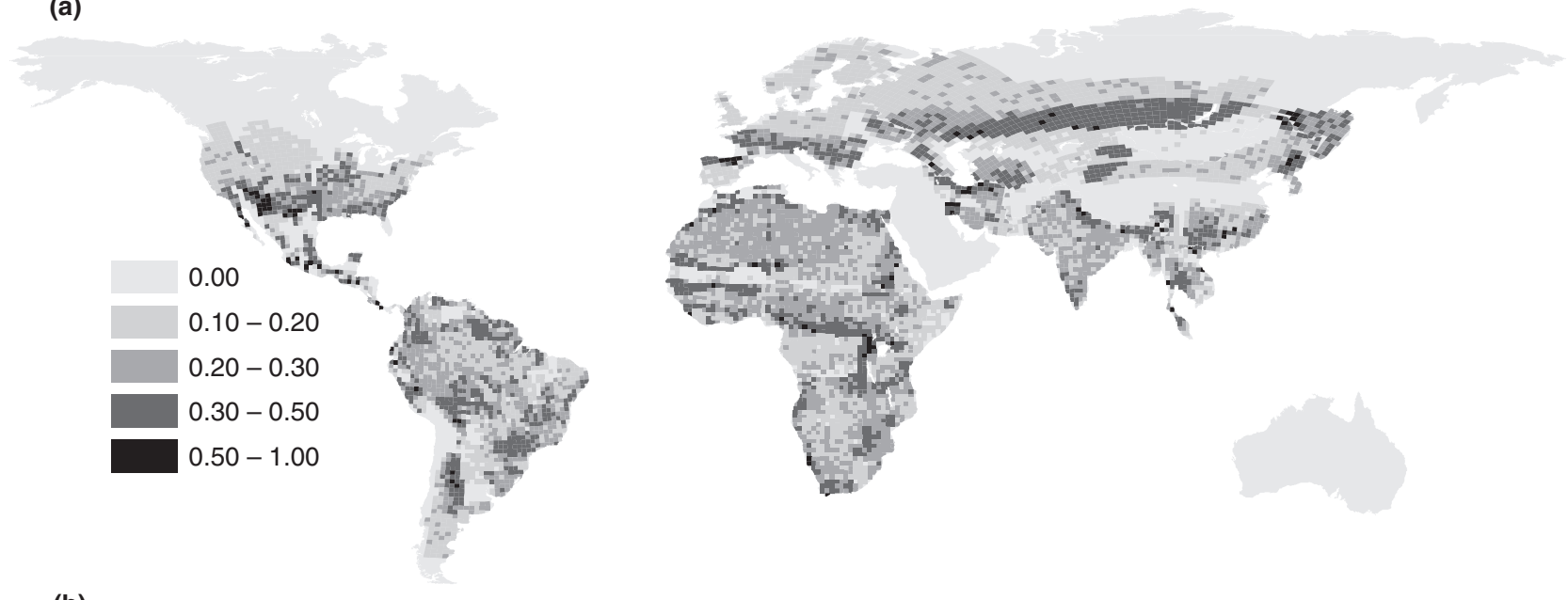

(b)
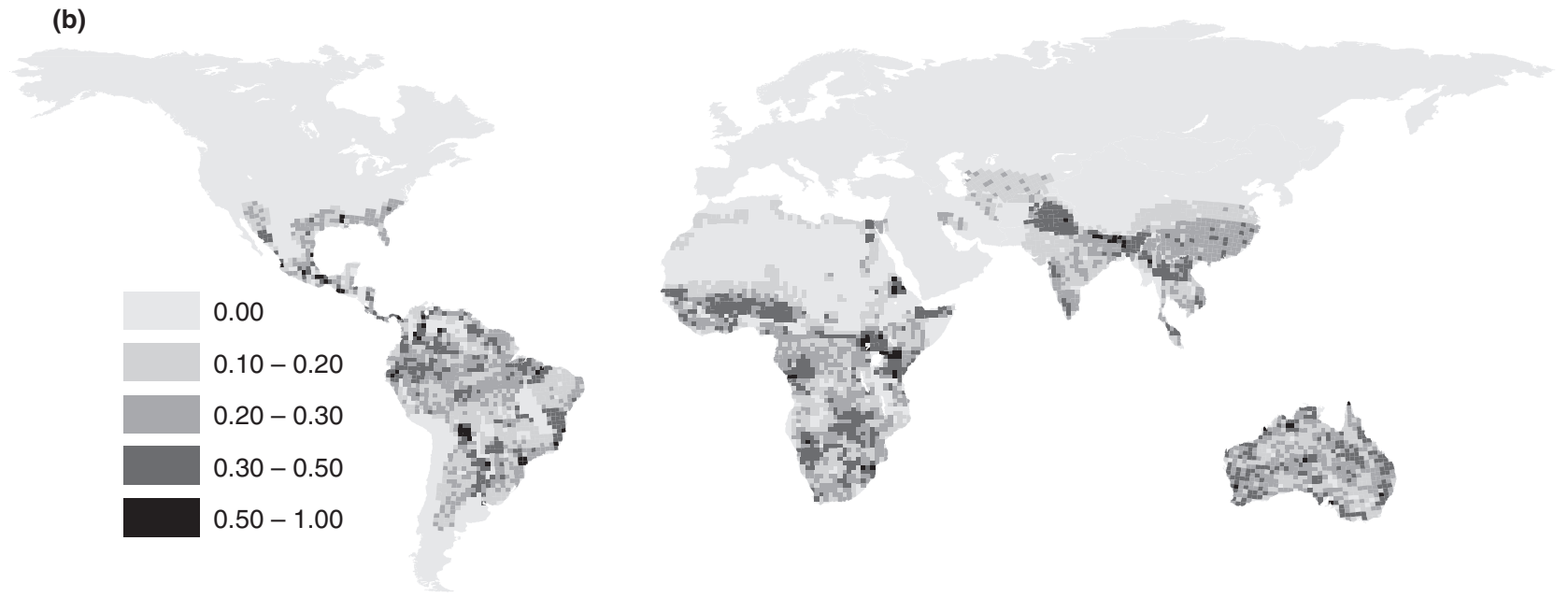

Figure 1 Global pattern of irreplaceability for Viperidae (a) and Elapidae (b).

Table 1 Number of $110 \times 110 \mathrm{~km}$ cells of the reserve networks obtained with a cost of high actual evapotranspiration (AET) and low human footprint (HF) in each of Cox's (2001) biogeographical region (see also Fig. 2). Values in parentheses represent the percentage of reserve network cells in each biogeographical region calculated from the total cells analysed for each group (i.e., 9563 for viperids and 9627 for elapids). AET + HF column represents the number of cells (and percentage) that are common in both reserve networks.

\begin{tabular}{|c|c|c|c|c|c|c|}
\hline \multirow[b]{2}{*}{ Biogeographical region/family (total cell number) } & \multicolumn{3}{|c|}{ Viperidae (9563) } & \multicolumn{3}{|c|}{ Elapidae (9627) } \\
\hline & AET & $\mathrm{HF}$ & $\mathrm{AET}+\mathrm{HF}$ & AET & HF & $\mathrm{AET}+\mathrm{HF}$ \\
\hline African & $504(21.3)$ & $561(23.7)$ & $133(5.6)$ & $325(13.7)$ & $384(16.2)$ & $91(3.8)$ \\
\hline Australian & - & - & - & $156(25.0)$ & $161(25.8)$ & $45(7.2)$ \\
\hline Eurasian & $421(12.0)$ & $469(13.4)$ & $132(3.7)$ & $49(1.4)$ & $56(1.6)$ & $16(0.4)$ \\
\hline North American & $134(8.7)$ & $137(8.9)$ & $48(3.1)$ & $29(1.9)$ & $32(2.1)$ & $8(0.5)$ \\
\hline Oriental & $144(24.5)$ & $135(22.9)$ & $45(7.6)$ & $136(23.1)$ & $149(25.3)$ & $49(8.3)$ \\
\hline South American & $324(20.3)$ & $336(21.1)$ & $100(6.2)$ & $291(18.3)$ & $307(19.3)$ & $86(5.4)$ \\
\hline Total & $1527(15.9)$ & $1638(17.1)$ & $458(4.7)$ & $986(10.2)$ & $1089(11.3)$ & $295(3.0)$ \\
\hline
\end{tabular}

conservation and human needs (Margules \& Pressey, 2000). Our analyses showed where it is possible to establish conservation priorities that represent the targets according to the established goals and, at the same time, minimize undesirable impacts caused by high human footprint. These networks give an initial picture of the most important areas to preserve viperid and elapid biodiversity in expectation of low conflicts between human development and conservation. However, our analyses also reveal that it may be problematic that few areas minimizing conflicts with human footprint were common to those areas of high environmental suitability. Also, when considering the nine global conservation schemes defined by Brooks et al. (2006), although $30 \%$ of cells of the lowest human influence reserve networks are contained in Last of the 
Table 2 Values of adjusted mean irreplaceability $\left(I_{\text {aj }}\right)$ from ANOVA calculated between 'groups' of cells coinciding (1) and not coinciding (0) with the areas of each global conservation priority scheme fitted within the conceptual framework of irreplaceability relative to vulnerability (see Brooks et al., 2006). Proportional gains in irreplaceability for each family in each global conservation scheme were calculated as the difference between mean adjusted irreplaceability in 0 and 1 divided by the mean adjusted irreplaceability in 0 . Cell percentages for cost solutions involving actual evapotranspiration (AET) and human footprint (HF) that match the areas covered by each of the nine global prioritization schemes are also given (cell \%) (see Methods). Bold values represent global schemes for which there was a gain in irreplaceability. Bold underlined value represents the global scheme for which there was a loss in irreplaceability.

Global conservation priority scheme

\begin{tabular}{|c|c|c|c|c|c|c|c|}
\hline \multirow[b]{2}{*}{ Scheme denomination and (abbreviation) } & \multicolumn{2}{|c|}{ Scheme prioritization } & \multicolumn{2}{|l|}{$I_{\mathrm{aj}}$} & \multirow{2}{*}{$\begin{array}{l}\text { Proportional gain } \\
\text { in irreplaceability }\end{array}$} & \multicolumn{2}{|c|}{ Cell \% } \\
\hline & Irreplaceability & Vulnerability & 1 & 0 & & AET & $\mathrm{HF}$ \\
\hline \multicolumn{8}{|l|}{ Viperidae } \\
\hline Biodiversity Hotspots (BH) & High & High & 0.233 & 0.221 & 0.054 & 22.4 & 20.4 \\
\hline Crisis Ecoregions (CE) & - & High & 0.228 & 0.221 & 0.031 & 21.9 & 18.3 \\
\hline Centers of Plant Diversity (CPD) & High & - & 0.237 & 0.221 & 0.072 & 23.5 & 22.3 \\
\hline Endemic Bird Areas (EBA) & High & - & 0.238 & 0.219 & 0.086 & 23.8 & 22.6 \\
\hline Frontier Forests $(\mathrm{FF})$ & - & Low & 0.229 & 0.223 & 0.026 & 24.0 & 29.3 \\
\hline Global 200 ecoregions (G200) & High & - & 0.225 & 0.224 & 0.004 & 21.4 & 22.2 \\
\hline High-Biodiversity Wilderness Areas (HBWA) & High & Low & 0.241 & 0.221 & 0.090 & 25.1 & 25.7 \\
\hline Last of the Wild (LW) & - & Low & 0.227 & 0.223 & 0.017 & 21.3 & 30.3 \\
\hline Megadiversity Countries (MC) & High & - & 0.231 & 0.219 & 0.054 & 22.3 & 21.4 \\
\hline \multicolumn{8}{|l|}{ Elapidae } \\
\hline Biodiversity Hotspots (BH) & High & High & 0.228 & 0.225 & 0.013 & 21.1 & 22.6 \\
\hline Crisis Ecoregions (CE) & - & High & 0.228 & 0.224 & 0.017 & 21.1 & 20.0 \\
\hline Centers of Plant Diversity (CPD) & High & - & 0.228 & 0.226 & 0.008 & 21.5 & 24.7 \\
\hline Endemic Bird Areas (EBA) & High & - & 0.245 & 0.215 & 0.139 & 25.0 & 23.1 \\
\hline Frontier Forests $(\mathrm{FF})$ & - & Low & 0.237 & 0.223 & 0.062 & 25.0 & 27.0 \\
\hline Global 200 ecoregions (G200) & High & - & 0.228 & 0.222 & 0.027 & 21.0 & 23.5 \\
\hline High-Biodiversity Wilderness Areas (HBWA) & High & Low & 0.229 & 0.225 & 0.017 & 22.0 & 25.1 \\
\hline Last of the Wild (LW) & - & Low & 0.216 & 0.231 & $\underline{-0.064}$ & 20.7 & 29.4 \\
\hline Megadiversity Countries (MC) & High & - & 0.234 & 0.214 & 0.093 & 22.7 & 22.5 \\
\hline
\end{tabular}

Authors of global conservation priority schemes are as follows: BH, Myers et al. (2000); CE, Hoekstra et al. (2005); CPD, WWF \& IUCN (1994-1997); EBA, Stattersfield et al. (1998); FF, Bryant et al. (1997); G200, Olson \& Dinerstein (2002); HBWA, Mittermeier et al. (2003); LW, Sanderson et al. (2002); MC, Mittermeier et al. (1997).

Wild areas, these areas have low conservation value for both Viperidae and Elapidae, as showed by the irreplaceability analyses (see Table 1).

On the other hand, a quarter of the cells of the reserve networks with highest possible AET match with areas whose conservation value is high for both groups (e.g., Endemic Bird Areas and High-Biodiversity Wilderness Areas). It seems plausible, therefore, that conservation strategies to preserve viperid and elapid biodiversity are focused mainly on the areas of high environmental suitability despite not minimizing conservation-human development conflicts, given that areas with low potential conflicts have lower irreplaceability values. Anyway, it is still possible to find overlapping areas that satisfy both low conflicts (i.e., low human influence) and high AET. In practice, these areas are the most appropriate to implement conservation actions for snake species preservation.

Efforts to identify conservation priorities at large scales have been criticized mainly because the priorities defined for some groups have failed to reflect diversity and rarity patterns for other groups (e.g., Mace et al., 2000; Rodrigues et al., 2004;
Grenyer et al., 2006). It has been recommended, for instance, that conservation strategies should be developed with independent datasets from several taxa (Mace et al., 2000). It is clear that considerable results would be achieved if we are able to include the largest amount of biodiversity data as possible in these global priority analyses. The problem is that complete information on species distributions and other data in large scales is often scarce for most groups of organisms (Raven \& Wilson, 1992; Lamoreux et al., 2006) and, in the face of dramatic loss of species, conservationists cannot afford waiting for comprehensive biodiversity datasets to become available (Balmford \& Gaston, 1999; Bini et al., 2006).

Moreover, Bode et al. (2008) showed that, although biodiversity data on all taxa will remain essential to global conservation prioritization, efficient conservation decisions are somewhat robust to the choice of taxon. These authors pointed out that 'efficiency gains will be most marked if conservation research focuses on obtaining better information on socioeconomic factors such as the costs of conservation action' (Bode et al., 2008: 6500). In this sense, the initiative of Brooks et al. 
(a)

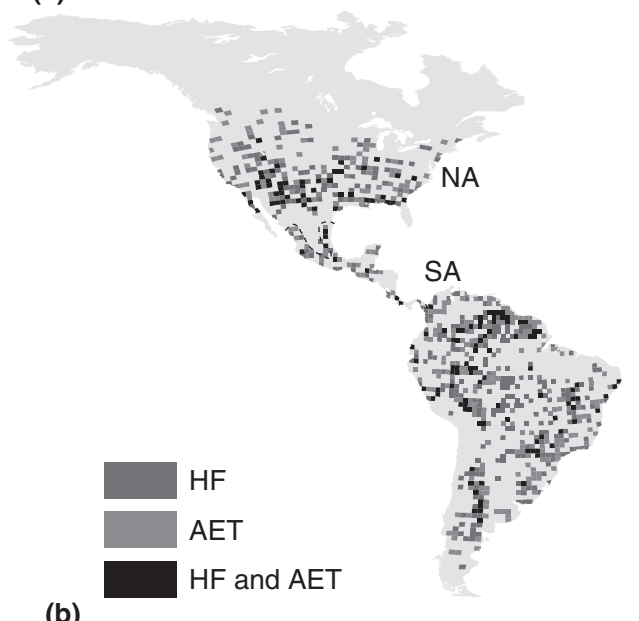

(b)

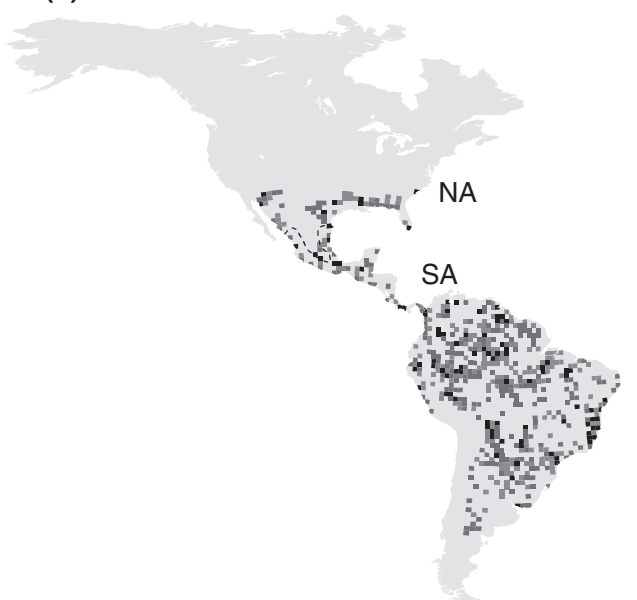

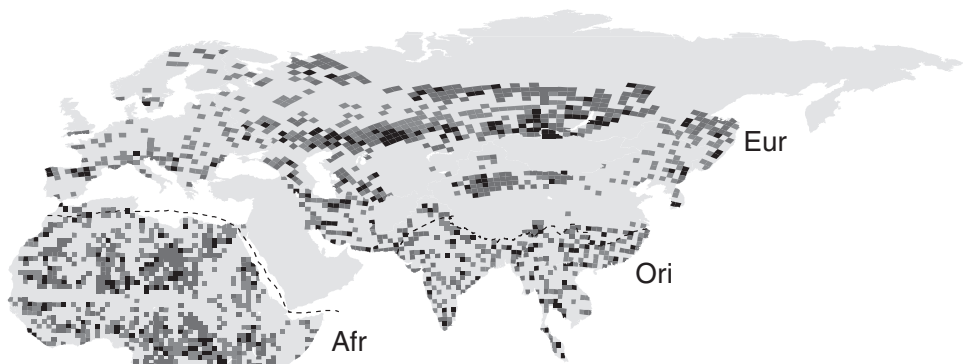
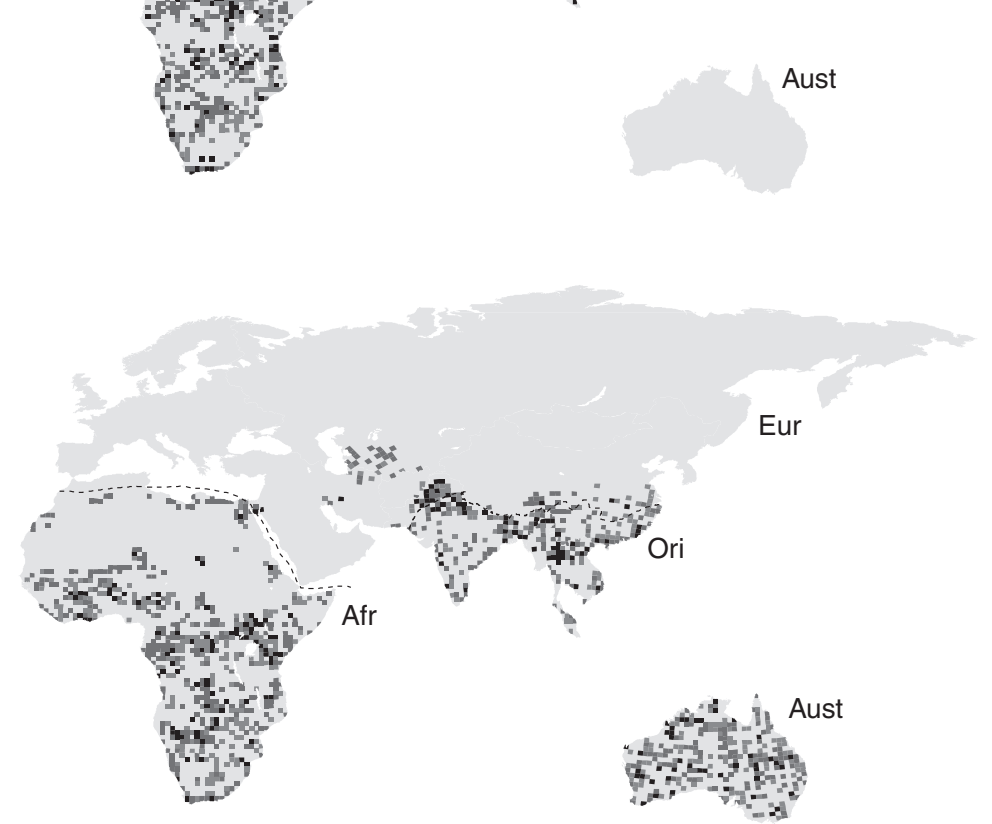

Figure 2 Spatial configuration of $110 \times 110$ cells chosen to represent the Viperidae (a) and Elapidae (b) biodiversity in a set with minimum human influence (light gray cells) and maximum AET (dark gray cells). Black cells represent the ones that were chosen in both solutions. HF, human footprint; AET, actual evapotranspiration. Dashed lines separate biogeographical regions as described by Cox (2001): North American (NA), South American (SA), African (Afr), Eurasian (Eur), Oriental (Ori) and Australian (Aust).

(2006) is of great importance because it enables us to compare the effectiveness of the current global conservation systems in representing conservation strategies for others groups of organisms as additional biodiversity datasets at broad scales become available. Also, the elucidation of proactive and reactive schemes can be used to interpret the level of threat for particular taxa, because if the most irreplaceable areas overlap with the reactive priorities, we can expect that they are under risk unless immediate conservation action is taken within these priorities (Brooks et al., 2006).

Our analyses can be useful in showing how priorities for a particular group of organisms (in this case, viperid and elapid snakes) can match global schemes, and in the long term, it may be easier to establish the frequency that each of these schemes is more appropriate for representing different groups of organisms than to match irreplaceabilites or reserve networks designed for particular groups, or even easier than finding overall biodiversity surrogates. We showed in this study that the priorities for which a gain in both irreplaceability and proportion of cells of the cost networks occurred were those designed as proactive. These findings are quite encouraging because they indicate the existence of viable conservation opportunities for these two snake groups. Viperids can benefit from the establishment of protected areas within the HighBiodiversity Wilderness Areas (e.g., Amazonian forest and African tropical forests) and Endemic Bird Areas (e.g., Brazilian Atlantic forest). The latter is also important to preserve elapid biodiversity, as well as the areas encompassed by the Megadiversity Countries.

However, it is important to note that, at least for viperids, regions of high irreplaceability matched also with the reactive priorities, whose areas are highly threatened (i.e., Centres of Plant Diversity) and vulnerable (i.e., Biodiversity Hotspots) (see Brooks et al., 2006). This is problematic given that more than $70 \%$ of the primary habitat from Biodiversity Hotspots has already been lost (Myers et al., 2000), and several studies have shown that habitat destruction is a serious threat to viperid (e.g., Zamudio \& Greene, 1997; Parkinson et al., 2001; Santos et al., 2006; Pleguezuelos et al., 2007) as well as elapid species (e.g., Shine \& Fitzgerald, 1989; Terribile et al., 2007) 
throughout their ranges. It is important that more detailed data at population level (i.e., minimum viable population models and data on area available with suitable habitats within hotspots) are obtained, so that overall efficiency of reactive schemes is evaluated for these particular groups of organisms (see e.g., Reed \& Shine, 2002).

Additionally, analogous to other groups of organisms (e.g., Hawkins et al., 2003b; Ceballos \& Ehrlich, 2006; Buckley \& Jetz, 2007), the peaks of Viperidae and Elapidae species richness occur at tropical regions (Terribile et al., 2009; see also Pauwels et al., 2008), which are often the most threatened and poorest economically (Gaston, 2000, 2007; Brooks et al., 2006). Thus, conservation strategies even within those areas threatened by high human densities are still necessary to preserve natural areas and refuges to protect rare and endemic snake species.

In conclusion, our analyses represent the first attempt to incorporate two clades of snakes into the context of global conservation priorities. Notwithstanding, there is still a pressing need to future work that will include other squamate reptiles (e.g., 'colubrid' snakes, lizards and amphisbaenians), which hitherto have been overlooked from broad-scale assessments of conservation priorities. Moreover, the analyses performed in this study can be viewed as an alternative approach to the recent criticism concerning the independent development of several global conservation priorities by different non-governmental organizations, which have led to a considerable redundancy in the results and few effective actions (Fonseca et al., 2000; Mace et al., 2000). The idea is that instead of simply evaluating the match of diversity patterns to a unique scheme (e.g., hotspots) and identifying matching problems (Grenyer et al., 2006), it is possible to compare the fit of different schemes, and understand the reasons behind this (see Loyola et al., 2009). Over time, as more analyses are conducted, it may become apparent if there is one that is useful for evaluating conservation priorities for all groups or for a set of particular groups of organisms. Thus, more than simply determining priorities for conservation of two snake clades, our analyses showed that the development of parallel priority-setting initiatives can be reconciled with those strategies for which financial resources are already being designed.

\section{ACKNOWLEDGEMENTS}

We thank R. Loyola, C. Nogueira, R. Tidon, G. Colli and the three anonymous reviewers for their useful suggestions. L.C.T. receives financial support from CAPES. Work by J.A.F.D.-F. was supported by a CNPQ researcher fellowship. The Spanish Ministry of Science and Innovation supported M.Á.R. (grant: CGL2006-03000/BOS).

\section{REFERENCES}

Akani, G.C., Barieenee, I.F., Capizzi, D. \& Luiselli, L. (1999) Snake communities of moist rainforest and derived savanna sites of Nigeria: biodiversity patterns and conservation priorities. Biodiversity and Conservation, 8, 629-642.
Alvarado-Díaz, J. \& Campbell, J.A. (2004) A new montane rattlesnake (Viperidae) from Michoacán, Mexico. Herpetologica, 60, 281-286.

Ananjeva, N.B., Orlov, N.L., Khalikov, R.G., Darevsky, I.S., Ryabov, S.A. \& Barabanov, A.V. (2006) The reptiles of Northen Eurasia: taxonomic diversity, distribution, conservation status. Pensoft Publishers, Sofia-Moscow.

Andelman, S., Ball, I., Davis, F. \& Stoms, D. (1999) SITES v. 1.0, an analytical toolbox for designing ecoregional conservation portfolios. Technical report, The Nature Conservancy, Available at: http://www.biogeog.ucsb.edu/projects/tnc/tool box.html (last accessed 11 November 2007).

Arnold, E.N. (2002) A field guide to the reptiles and amphibians of Britain and Europe. Harper Collins, London.

Arnold, E.N. \& Ovenden, D.W. (2002) Reptiles and amphibians of Europe. Princeton University Press, Princeton.

Balmford, A. \& Gaston, K.J. (1999) Why biodiversity surveys are good value. Nature, 398, 204-205.

Balmford, A., Moore, J.L., Brooks, T., Burgess, N., Hansen, L.A., Williams, P. \& Rahbek, C. (2001) Conservation conflicts across Africa. Science, 291, 2616-2619.

Balmford, A., Gaston, K.J., Blyth, S., James, A. \& Kapos, V. (2003) Global variation in terrestrial conservation costs, conservation benefits, and unmet conservation needs. Proceedings of the National Academy of Sciences, USA, 100, 1046-1050.

Bini, L.M., Diniz-Filho, J.A.F., Rangel, T.F.L.V.B., Bastos, R.P. \& Pinto, M.P. (2006) Challenging Wallacean and Linnean shortfalls: knowledge gradients and conservation planning in a biodiversity hotspot. Diversity and Distributions, 12, 475-482.

Bode, M., Wilson, K.A., Brooks, T.M., Turner, W.R., Mittermeier, R.A., McBride, M.F., Underwood, E.C. \& Possingham, H.P. (2008) Cost-effective global conservation spending is robust to taxonomic group. Proceedings of the National Academy of Sciences USA, 105, 6498-6501.

Branch, B. (1988) Field Guide to the snakes and other reptiles of Southern Africa, 1st edn. New Holland, London.

Branch, B. (1998) Field Guide to snakes and other reptiles of Southern Africa, 3rd edn. Ralph Curtis Books Publishing, Florida.

Broadley, D.G. \& Doria, C.T. (2003) Snakes of Zambia: an atlas and field guide. Edition Chimaira, Frankfurt am Main.

Brooks, T.M., Balmford, A., Burgess, N., Fjeldså, J., Hansen, L.A., Moore, J., Rahbek, C. \& Williams, P. (2001) Toward a blueprint for conservation in Africa. BioScience, 51, 613-624.

Brooks, T.M., Mittermeier, R.A., Fonseca, G.A.B., Gerlach, J., Hoffmann, M., Lamoreux, J.F., Mittermeier, C.G., Pilgrim, J.D. \& Rodrigues, A.S.L. (2006) Global biodiversity conservation priorities. Science, 313, 58-61.

Bryant, D., Nielsen, D. \& Tangley, L. (1997) Last Frontier Forests: ecosystems and economies on the edge. World Resources Institute, Washington.

Buckley, L.B. \& Jetz, W. (2007) Environmental and historical constraints on global patterns of amphibian richness. Proceedings of the Royal Society B, 274, 1167-1173. 
Cagle, N.L. (2008) Snake species distributions and temperate grasslands: a case study from the American tallgrass prairie. Biological Conservation, 141, 744-755.

Campbell, J.A. \& Lamar, W.W. (2004) The venomous reptiles of the Western Hemisphere, Vol I and II. Cornell University Press, New York, NY.

Carwardine, J., Rochester, W.A., Richardson, K.S., Williams, K.J., Pressey, R.L. \& Possingham, H.P. (2007) Conservation planning with irreplaceability: does the method matter? Biodiversity and Conservation, 16, 245-258.

Carwardine, J., Wilson, K.A., Ceballos, G., Ehrlich, P.R., Naidoo, R., Iwamura, T., Hajkowicz, S.A. \& Possingham, H.P. (2008) Cost-effective priorities for global mammal conservation. Proceedings of the National Academy of Sciences, USA, 105, 11446-11450.

Ceballos, G. \& Ehrlich, P.R. (2006) Global mammal distributions, biodiversity hotspots, and conservation. Proceedings of the National Academy of Sciences, USA, 103, 19374-19379.

Ceballos, G., Ehrlich, P.R., Soberón, J., Salazar, I. \& Fay, J.P. (2005) Global mammal conservation: what must we manage? Science, 309, 603-607.

Cherlin, V.A. (1981) The new saw-scaled viper Echis multisquamatus sp. nov. from south-western and Middle Asia [in Russian]. Trudy Zoologiceskogo Instituta, 101, 92-95.

Chown, S.L., Van Rensburg, B.J., Gaston, K.J., Rodrigues, A.S.L. \& Van Jaarsveld, A.S. (2003) Energy, species richness, and human population size: conservation implications at a national scale. Ecological Applications, 13, 1233-1241.

Cogger, H., Cameron, E., Sadlier, R. \& Eggler, P. (2000) The actions plan for Australian reptiles. Australian Nature Conservation Agency, Sydney.

Couto, L.F., Terribile, L.C. \& Diniz-Filho, J.A.F. (2007) Padrões espaciais e conservação da diversidade de serpentes do bioma cerrado. Acta Scientiarum Biological Sciences, 29, 65-73.

Cox, C.B. (2001) The biogeographic regions reconsidered. Journal of Biogeography, 28, 511-523.

Currie, D.J. (1991) Energy and large-scale patterns of animaland plant-species richness. American Naturalist, 137, 27-49.

Currie, D.J., Mittelbach, G.G., Cornell, H.V., Field, R., Guegan, J.-F., Hawkins, B.A., Kaufman, D.M., Kerr, J.T., Oberdorff, T., O'Brien, E.M. \& Turner, J.R.G. (2004) Predictions and tests of climate-based hypotheses of broad-scale variation in taxonomic richness. Ecological Letters, 7, 1121-1134.

Diniz-Filho, J.A.F., Bini, L.M., Pinto, M.P., Rangel, T.F.L.V.B., Carvalho, P. \& Bastos, R.P. (2006) Anuran species richness, complementarity and conservation conflicts in Brazilian Cerrado. Acta Oecologica, 29, 9-15.

Dobiey, M. \& Vogel, G. (2007) Venomous snakes of Africa. Edition Chimaira, Frankfurt am Main.

Dodd, C.K. Jr (1987) Status, conservation, and management. Snakes: ecology and evolutionary biology (ed. by R.A. Seigel, J.T. Collins and S.S. Novak), pp. 478-513. MacMillan, New York, NY.

Dodd, C.K. Jr (1993) Strategies for snake conservation. Snakes: ecology and behavior (ed. by R.A. Seigel and J.T. Collins), pp. 363-393. Mc-Graw-Hill, New York, NY.
Ehrlich, P.R. (1994) Energy use and biodiversity loss. Philosophical Transactions of the Royal Society B, 344, 99-104.

Faith, D.P., Carter, G., Cassis, G., Ferrier, S. \& Wilkie, L. (2003) Complementarity, biodiversity viability analysis, and policy-based algorithms for conservation. Environmental Science and Policy, 6, 311-328.

Ferrier, S., Pressey, R.L. \& Barrett, T.W. (2000) A new predictor of the irreplaceability of areas for achieving a conservation goal, its application to real-world planning, and a research agenda for further refinement. Biological Conservation, 93, 303-325.

Filippi, E. \& Luiselli, L. (2000) Status of the Italian snake fauna and assessment of conservation threats. Biological Conservation, 93, 219-225.

Fonseca, G.A.B., Balmford, A., Bibby, C., Boitani, L., Corsi, F., Brooks, T., Gascon, C., Olivieri, S., Mittermeier, R., Burges, N., Dinerstein, E., Olson, D., Hannah, L., Lovett, J., Moyer, D., Rahbek, C., Stuart, S. \& Williams, P. (2000) Following Africa's lead in setting priorities. Nature, 405, 393-394.

Gaston, K.J. (2000) Global patterns in biodiversity. Nature, 405, 202-227.

Gaston, K.J. (2007) Latitudinal gradient in species richness. Current Biology, 17, R574.

Geniez, P. \& Tynié, A. (2005) Discovery of a population of the critically engangered Vipera darevskii Vedmederja, Orlov and Tuniyev 1986 in Turkey, with new elements on its identification (Reptilia: Squamata: Viperidae). Herpetozoa, 18, 25-33.

Gibbons, J.W., Scott, D.E., Ryan, J.T., Buhlmann, K.A., Tuberville, T.D., Metts, B., Greene, J.L., Mills, T.M., Lediden, Y.A., Poppy, S.M. \& Winne, C.T. (2000) The global decline of reptiles: déjà vu amphibians. BioScience, 50, 653666.

Grenyer, R., Orme, C.D.L., Jackson, S.F., Thomas, G.H., Davies, R.G., Davies, T.J., Jones, K.E., Olson, V.A., Ridgely, R.S., Rasmussen, P.C., Ding, T.-S., Bennett, P.M., Blackburn, T.M., Gaston, K.J., Gittleman, J.L. \& Owens, I.P.F. (2006) Global distribution and conservation of rare and threatened vertebrates. Nature, 444, 93-96.

Hawkins, B.A., Field, R., Cornell, H.V., Currie, D.J., Guégan, J.-F., Kaufman, D.M., Kerr, J.T., Mittelbach, G.G., Oberdorff, T., O’Brien, E.M., Porter, E.E. \& Turner, J.R.G. (2003a) Energy, water, and broad-scale geographic patterns of species richness. Ecology, 84, 3105-3117.

Hawkins, B.A., Porter, E.E. \& Diniz-Filho, J.A.F. (2003b) Productivity and history as predictors of the latitudinal diversity gradient of terrestrial birds. Ecology, 84, 1608-1623.

Hoekstra, J.M., Boucher, T.M., Ricketts, T.H. \& Roberts, C. (2005) Confronting a biome crisis: global disparities of habitat loss and protection. Ecological Letters, 8, 23-29.

IUCN, Conservation International \& NatureServe (2006) Global Amphibian Assessment. Available at: http://www. globalamphibians.org (accessed 18 August 2008).

Jaggi, C. \& Baur, B. (1999) Over growing forest as a possible cause for the local extinction of Vipera aspis in the northern Swiss Jura mountains. Amphibia-Reptilia, 20, 25-34. 
Kelly, C.M.R., Barker, N.P. \& Villet, M.H. (2003) Phylogenetics of advanced snakes (Caenophidia) based on four mitochondrial genes. Systematic Biology, 52, 439-459.

Khan, S. (2002) Venomous terrestrial snakes of Pakistan. Available at: http://www.wildlifeofpakistan.com/Reptilesof Pakistan/venomousterrestrialsnakesofPakistan.htm (accessed 3 April 2007).

Krebs, C.J. (1998) Ecological methodology. Addison Wesley Longman, Menlo Park, CA.

Lamoreux, J.F., Morrison, J.C., Ricketts, T.H., Olson, D.M., Dinerstein, E., McKnight, M.W. \& Shugart, H.H. (2006) Global tests of biodiversity concordance and the importance of endemism. Nature, 440, 212-214.

Latifi, M. (1991) The snakes of Iran. Society for the study of Amphibians and Reptiles, Oxford.

Lavin-Murcio, P.A. \& Dixon, J.R. (2004) A new species of coral snake (Serpentes, Elapidae) from the Sierra de Tamaulipas, Mexico. Phyllomedusa, 3, 3-7.

Loyola, R.D., Oliveira, G., Diniz-Filho, J.A.F. \& Lewinsohn, T.M. (2008) Conservation of Neotropical carnivores under different prioritization scenarios: mapping species traits to minimize conservation conflicts. Diversity and Distributions, 14, 949-960.

Loyola, R.D., Kubota, U., Fonseca, G.A.B. \& Lewinsohn, T.M. (in press) Key neotropical ecoregions for conservation of terrestrial vertebrates. Biodiversity and Conservation. doi: 10.1007/s10531-008-9570-6.

Mace, G.M., Balmford, A., Boitani, L., Cowlishaw, G., Dobson, A.P., Faith, D.P., Gaston, K.J., Humphries, C.J., Vane-Wright, R.I., Williams, P.H., Lawton, J.H., Margules, C.R., May, R.M., Nicholls, A.O., Possingham, H.P., Rahbek, C. \& van Jaarseveld, A.S. (2000) It's time to work together and stop duplicating conservation efforts. Nature, 405, 393.

Mallow, D., Ludwig, D. \& Nilson, G. (2003) True vipers: natural history and toxinology of Old World vipers. Krieger Publishing Company, Florida.

Margules, C.R. \& Pressey, R.L. (2000) Systematic conservation planning. Nature, 405, 243-253.

Meir, E., Andelman, S. \& Possingham, H.P. (2004) Does conservation planning matter in a dynamic and uncertain world? Ecological Letters, 7, 615-622.

Mittermeier, R.A., Robles-Gil, P. \& Mittermeier, C.G. (1997) Megadiversity: earth's biologically wealthiest nations. CEMEX, Monterrey, Mexico.

Mittermeier, C.G., Brooks, T.M., Pilgrim, J.D., Konstant, W.R., Fonseca, G.A.B. \& Kormos, C. (2003) Wilderness and biodiversity conservation. Proceedings of the National Academy of Sciences, USA, 100, 10309-10313.

Moore, J., Balmford, A., Brooks, T., Burgess, N., Hansen, L.A., Rahbek, C. \& Williams, P. (2003) Performance of SubSaharan vertebrates as indicator groups for identifying priority areas for conservation. Conservation Biology, 17, 207-218.

Myers, N., Mittermeier, R.A., Mittermeier, C.G., Fonseca, G.A.B. \& Kent, J. (2000) Biodiversity hotspots for conservation priorities. Nature, 403, 853-858.
Nilson, G., Andren, C., Ioannidis, Y. \& Dimaki, M. (1999) Ecology and conservation of the Milos viper, Macrovipera schweizeri (Werner, 1935). Amphibia-Reptilia, 20, 355375.

O'Brien, M.E. (2006) Biological relativity to water-energy dynamics. Journal of Biogeography, 33, 1868-1888.

Olson, D.M. \& Dinerstein, E. (2002) The global 200: priority ecoregions for global conservation. Annals of the Missouri Botanical Garden, 89, 199-224.

Orlov, N.L. \& Tuniyev, B.F. (1990) Three species in the Vipera kaznakowi complex (Eurosiberian Group) in the Caucasus: their present distribution, possible genesis, and phylogeny. Asiatic Herpetological Research, 3, 1-36.

Parkinson, C.L., Zamudio, K.R. \& Greene, H.W. (2001) Phylogeography of the pitviper clade Agkistrodon: historical ecology, species status, and conservation of cantils. Molecular Ecology, 9, 411-420.

Pauwels, O.S.G., Wallach, V. \& David, P. (2008) Global diversity of snakes (Serpentes; Reptilia) in freshwater. Hydrobiologia, 595, 599-605.

Pimm, S.L., Russel, G.J., Gittleman, J.L. \& Brooks, T.M. (1995) The future of biodiversity. Science, 269, 347-350.

Pleguezuelos, J.M., Santos, X., Brito, J.C., Parellada, X., Llorente, G.A. \& Fahd, S. (2007) Reproductive ecology of Vipera latastei, in the Iberian Peninsula: implications for the conservation of a Mediterranean viper. Zoology, 110, 9-19.

Raven, P.H. \& Wilson, E.O. (1992) A fifty-year plan for biodiversity surveys. Science, 258, 1099-1100.

Redford, K.H., Coppolillo, P., Sanderson, E.W., Fonseca, G.A.B., Dinerstein, E., Groves, C., Mace, G., Maginnis, S., Mittermeier, R.A., Noss, R., Olson, D., Robinson, J.G., Vedder, A. \& Wright, M. (2003) Mapping the conservation landscape. Conservation Biology, 17, 116-131.

Reed, R.N. \& Shine, R. (2002) Lying in wait for extinction: ecological correlates of conservation status among Australian elapid snakes. Conservation Biology, 16, 451-461.

Renjifo, J.M. \& Lundberg, M. (2003) Una especie nueva de serpiente coral (Elapidae, Micrurus), de la region de Urra, municipio de Tierra Alta, Cordoba, noroccidente de Colombia. Revista de la Academia Colombiana de Ciencias Exactas, Físicas y Naturales, 27, 141-144.

Rodrigues, A.S.L., Andelman, S.J., Bakarr, M.I., Boitani, L., Brooks, T.M., Cowling, R.M., Fishpool, L.D.C., Fonseca, G.A.B., Gaston, K.J., Hoffmann, M., Long, J.S., Marquet, P.A., Pilgrim, J.D., Pressey, R.L., Schipper, J., Sechrest, W., Stuart, S.N., Underhill, L.G., Waller, R.W., Watts, M.E.J. \& Yan, X. (2004) Effectiveness of the global protected area network in representing species diversity. Nature, 428, 640-643.

Sanderson, E.W., Jaiteh, M., Levy, M.A., Redford, K.H., Wannebo, A.V. \& Woolmer, G. (2002) The human footprint and the last of the wild. BioScience, 52, 891-904.

Santos, X., Brito, J.C., Sillero, N., Pleguezuelos, J.M., Llorente, G.A., Fahd, S. \& Parellada, X. (2006) Inferring habitat-suitability areas with ecological modelling techniques and GIS: a contribution to assess the conservation status of Vipera latastei. Biological Conservation, 130, 416-425. 
Shine, R. \& Fitzgerald, M. (1989) Conservation and reproduction of an endangered species: the broad-headed snake, Hoplocephalus bungaroides (Elapidae). Australian Zoologist, 25, 65-67.

Sokal, R.R. \& Rohlf, F.J. (1995) Biometry: the principles and practice of statistics in biological research, 3rd edn. W. $\mathrm{H}$. Freeman and Co., New York, NY.

Spawls, S., Howell, K., Drewes, R. \& Ashe, J. (2004) A field guide to the reptiles of East Africa. A\&C Black Publishers, London and San Diego.

Stattersfield, A.J., Crosby, M.J., Long, A.J. \& Wege, D.C. (1998) Endemic bird areas of the world. BirdLife International, Cambridge.

Terribile, L.C., Anacleto, T.C.S., Silva, N.J. Jr \& Diniz-Filho, J.A.F. (2007) Potential geographic distribution of the coralsnake Micrururus decoratus Jan, 1858 (Serpentes, Elapidae) in the Atlantic rain forest of Brazil. Arquivos do Museu Nacional, 65, 217-223.

Terribile, L.C., Olalla-Tárraga, M.Á., Morales-Castilla, I., Rueda, M., Vidanes, R.M., Rodríguez, M.Á. \& Diniz-Filho, J.A.F. (2009) Global richness patterns of venomous snakes reveal contrasting influences of ecology and history in two different clades. Oecologia, 159, 617-626.

Tuniyev, B.S. \& Ostrovskikh, S.V. (2001) Two new species of vipers of "kaznakovi" complex (Ophidia, Viperinae) from the Western Caucasus. Russian Journal of Herpetology, 8, 117-126.
Uetz, P. (2007) The Reptile Database. Available at: http:// www.reptile-database.org (accessed 10 May 2007).

Vogel, G. (2006) Venomous snakes of Asia. Edition Chimaira, Frankfurt am Main.

Webb, J.K., Brook, B.W. \& Shine, R. (2002) What makes a species vulnerable to extinction? Comparative life-history traits of two sympatric snakes. Ecological Research, 17, 59-67.

Williams, P.H. (1998) Key sites for conservation: area-selection methods for biodiversity. Conservation in a changing world (ed. by G.M. Mace, A. Balmford and J.R. Ginsberg), pp. 211249. Cambridge University Press, Cambridge.

Wilson, S. \& Swan, G. (2003) Reptiles of Australia. Princeton University Press, Princeton and Oxford.

WWF \& IUCN. (1994-1997) Centres of Plant Diversity. WWF and IUCN, Gland, Switzerland.

Zamudio, K.R. \& Greene, H.W. (1997) Phylogeography of the bushmaster (Lachesis muta: Viperidae): implications for neotropical biogeography, systematics, and conservation. Biological Journal of the Linnean Society, 62, 421-442.

Zhou, Z. \& Jiang, Z. (2005) Identifying snake species threatened by economic exploitation and international trade in China. Biodiversity and Conservation, 14, 3525-3536.

Editor: Jon Paul Rodriguez 